\title{
REVISION OF RECIPROCAL ACTION OF MERCURY AND SELENIUM
}

\section{RENATA KURAŚ, BEATA JANASIK, MAGDALENA STANISŁAWSKA, and WOJCIECH WĄSOWICZ}

\author{
Nofer Institute of Occupational Medicine, Łódź, Poland \\ Department of Biological and Environmental Monitoring, Metal Analyses Laboratory
}

\begin{abstract}
Diverse forms of mercury $(\mathrm{Hg})$ have various effects on animals and humans because of a variety of routes of administration. Inorganic mercury (iHg) binds to thiol groups of proteins and enzymes in one's body or is methylated by microorganisms. Organic form of $\mathrm{Hg}$, contrary to the $\mathrm{iHg}$, is more stable but may be demethylated to $\mathrm{Hg}^{2+}$ in the tissue of intestinal flora. Selenium (Se) also occurs in a variety of chemical forms in one's body but both of these elements behave very differently from one another. Mercury binding to selenide or Se-containing ligands is a primary molecular mechanism that reduces toxicity of $\mathrm{Hg}$. Complexes formed in such a way are irreversible, and thus, biologically inactive. Se deficiency in a human body may impair normal synthesis of selenoproteins and its expression because expression of mRNA may be potentially regulated by the Se status. This paper provides a comprehensive review concerning $\mathrm{Hg}-\mathrm{Se}$ reciprocal action as a potential mechanism of protective action of Se against $\mathrm{Hg}$ toxicity as well as a potential detoxification mechanism. Although interactions between $\mathrm{Hg}-\mathrm{Se}$ have been presented in numerous studies concerning animals and humans, we have focused mainly on animal models so as to understand molecular mechanisms responsible for antagonism better. The review also investigates what conclusions have been drawn by researchers with respect to the chemical species of Se and $\mathrm{Hg}$ (and their relationship) in biological systems as well as genetic variations and expression and/or activity of selenoproteins related to the thioredoxin (thioredoxin Trx/TrxR) system and glutathione metabolism. Int J Occup Med Environ Health 2018;31(5):575-592
\end{abstract}

Key words:

Gene expression, Polymorphism, Mercury, Selenium, Antagonism, Interaction

\section{INTRODUCTION}

Since effects of the mercury-selenium $(\mathrm{Hg}-\mathrm{Se})$ interaction seem to be complex, more and more scientists are interested in the issue of potential $\mathrm{Hg}$ detoxification mechanism in the presence of Se. The undertaken issue will allow to disseminate knowledge concerning the influence of Se levels, its speciation forms and expression of selenoproteins on avoidance of adverse effects of $\mathrm{Hg}$. However, in order to explain the mechanisms of interaction of $\mathrm{Hg}-\mathrm{Se}$ in animals and humans, one should become thoroughly familiar with toxicokinetics of $\mathrm{Hg}$ which is diverse for the variety of its chemical forms.

There are differences in the kinetics and metabolism depending on $\mathrm{Hg}$ compounds, which exert impact on the animal as well as human body and interactions between various factors that cause biochemical changes in many metabolic reactions leading to respiratory [1], nervous system [2-4] and immune system disorders [5]. Its toxicity is also manifested in damaged kidneys $[6,7]$ and heart diseases $[8,9]$. Exposure to $\mathrm{Hg}$ reveals significant metabolic al-

Funding: this work was supported by Nofer Institute of Occupational Medicine (internal grant No. 1.31/2014 entitled "The study of the selenium - mercury interaction as a potential mercury detoxification mechanism among workers occupationally exposed to mercury," project manager: Prof. Wojciech Wąsowicz) and by the Ministry of Science and Higher Education in Poland (grant No. 2013/11/B/NZ7/04934 entitled "The impact of different exposure to mercury on selenium status in the context of mercury - selenium interaction as a potential detoxification mechanism," grant manager: Prof. Wojciech Wąsowicz).

Received: September 30, 2017. Accepted: January 26, 2018.

Corresponding author: Renata Kuraś, Nofer Institute of Occupational Medicine, Department of Biological and Environmental Monitoring, Metal Analyses Laboratory, św. Teresy 8, 91-348 Łódź, Poland (e-mail: renata.kuras@imp.lodz.pl). 
terations associated with the damage to the cell membrane and thus, decreasing or even blocking the biochemical function of proteins and other molecules of major biological significance (e.g., the glutathione system (GSH), glutathione peroxidase (GPx), thioredoxin reductase (TrxR)). Metallic mercury $\left(\mathrm{Hg}^{0}\right)$ is usually rapidly oxidized in the red blood cells by catalase (CAT) enzyme and hydrogen peroxide to bivalent ionic $\left(\mathrm{Hg}^{2+}\right.$ mercuric) and partly penetrates other tissues. The resulting $\mathrm{Hg}^{2+}$ is biologically active and has a very high affinity with sulfhydryl (thiol; -SH) groups of e.g., cysteine (Cys), homocysteine (Hcys) and $\mathrm{N}$-acetylcysteine (NAC) proteins.

Mercury and the sulfur (S) present in thiol groups form stable complexes, which leads to toxic effect of $\mathrm{Hg}$ at the molecular level. Since S and Se present in the same group of Mendeleev's periodic table, they are characterized by similar chemical properties. Selenium forms complexes with $\mathrm{Hg}$ and these complexes have been confirmed in numerous studies [10-13]. Irreversible and nonspecific binding to the protein causes vast changes in the protein conformation leading to its inhibition or denaturation. Since mercuric ion has weak ability to penetrate blood-brain barrier (BBB) back, it accumulates in brain and thus, impairs metabolism of the nervous system and gets from placenta to the fetus. It is associated with oxidation of $\mathrm{Hg}^{0}$ in the brain to $\mathrm{Hg}^{2+}$, where it accumulates. Chronic occupational exposure to $\mathrm{Hg}^{0}$ influences permeability of lysosomal membranes, which leads to urinary excretion of low molecular weight proteins (e.g., $\beta_{2}$-microglobulin $\left(\beta_{2}\right.$-M), retinol binding protein (RBP) and lysosomal enzymes, such as: $\beta$-galactosidase ( $\beta$-GAL), N-acetyl- $\beta$-D-glucosaminidase (NAG), and its isoenzyme (NAG-B), $\beta$-glucuronidase $(\beta$-Gr) $[14,15]$.

Bernard et al. [16] have shown that RBP, next to NAG, is one of the most sensitive markers of renal damage. Renal tubules damage is caused mainly by the interaction of $\mathrm{Hg}^{2+}$ with enzymes responsible for protection of a cell against redox balance disorders. In kidneys, mainly $\mathrm{Hg}^{2+}$ has affinity with metallothioneins (MTs), thus exposure to $\mathrm{Hg}^{0}$ affects induction of synthesis of MTs in kidneys. Metallothioneins as specific proteins, rich in cysteine with high affinity to metals, play a protective role against neurotoxic effect of $\mathrm{Hg}^{0}$ as well as against nephrotoxic effect of $\mathrm{Hg}^{2+}$, enabling its transportation and excretion. Metallic mercury effortlessly passes through the placental membrane and BBB. Organomercury (e.g., methylmercury $(\mathrm{MeHg})$ ) compounds are lipophilic, they also pass blood-brain, as well as placental barriers easily, which results in impairment of the nervous system metabolism. Because of $\mathrm{MeHg}$, which is a highly specific and irreversible inhibitor of Se-dependent enzymes, animals as well as humans require selenoenzymes to protect their organisms against oxidative damage [17].

Occupational as well as environmental exposure to $\mathrm{Hg}$ is the factor which induces upsetting the balance between creation of reactive oxygen species (ROS) and biological capacity of their detoxification. The redox imbalance may lead to enormous implications in antioxidant activity (stimulates formation of free radicals and ROS) and energy metabolism. Studies carried out so far have indicated the role of $\mathrm{Hg}$ in the induction of oxidative system [18-21]. Chronic toxic effect of $\mathrm{Hg}$ induces excessive generation of free radicals, which when reacting with components of the cell affect the redox potential. Reactive oxygen species impair structure of biological membranes of cells, among others, by lipid peroxidation, protein oxidation or DNA damage through modification of nitrogenous bases, or they induce cell apoptosis, the result of which is acceleration of neurodegenerative diseases, cardiovascular diseases and cancers.

Cebulska-Wasilewska et al. [22] claim that occupational exposure to $\mathrm{Hg}$ does not cause direct genotoxicity but causes significant deficiency in DNA repair. There is also data that indicates that 8-oxo-7,8-dihydro-2'-deoxyguanosine (8-oxodG) appearing in urine suggests oxida- 
tive DNA damage. The specific system of this damage repair involves a removal of oxidatively modified nucleoside (guanosine) and its excretion from the body [23,24]. The analysis of concentrations of 8-oxodG in urine may provide information about cell defense mechanism in response to $\mathrm{Hg}$-induced oxidative stress and free radicals. Li et al. [5] indicated that in the case of local people with long-term $\mathrm{Hg}$ exposure living in mining areas of Wanshan (China), after supplementation with Se (100 $\mu \mathrm{g}$ of organic Se daily in Se-enriched yeast), an increase in urinary $\mathrm{Hg}$ excretion and a decrease in oxidative stress-related biomarkers including 8-hydroxy-2-deoxyguanosine (8-OHdG) were observed.

Popular interest in Se as a primary antioxidant, immunological factor and simultaneously a metalloid inactivating toxic effects of $\mathrm{Hg}$ is large. It is mainly involved in metabolic pathways associated with regulation of the redox potential [25-27] but it may be toxic depending on its concentration and chemical forms [12]. Inorganic form of Se (iSe) occurs as salts and easily passes the placental barrier and BBB. Since selenite $\left(\mathrm{Se}^{4+}\right)$ has a higher affinity with tissue than selenate $\left(\mathrm{Se}^{6+}\right)$, it may form complexes with proteins. Inorganic form of Se compounds are converted into organic selenocomplexes and these complexes, especially in the second oxidation state, constitute the most available form of Se for humans. The major biological form of Se is selenocysteine, the 21st proteinogenic amino acid, which is related to its presence in the active center of selenoenzymes (especially GPx as the main enzymatic system which participates in the defense against free radicals Hg-induced and TrxR, which coordinates $\mathrm{Hg}$-induced redox reactions maintaining the proper cellular function) and Se-dependent proteins like selenoprotein $\mathrm{P}(\mathrm{SeP})$, the best known selenoprotein in plasma, which protects organism against $\mathrm{Hg}$ toxicity. Its selenol groups (-SeH) present in the multiple selenocysteine residues form complexes with $\mathrm{Hg}$, and thus contribute to its detoxification [28,29].

\section{METHODS}

Literature referred to in this review was identified via search of electronic databases, such as: PubMed, Scopus, Science Direct and Google Scholar and textbooks in the field of toxicology. The following search key words (or combinations of them) were applied: $\mathrm{Hg}, \mathrm{MeHg}$, Se, speciation, $\mathrm{Hg}-\mathrm{Se}$ interaction, $\mathrm{Hg}-\mathrm{Se}$ antagonism. Preferred Reporting Items for Systematic Reviews and Meta-Analyses (PRISMA) were used [30].

During literature search, 1888 citations were detected and 102 of them were selected for the review. All articles were defined according to the following categories of inclusion (data from published studies, literature published 1967-2017, the English language, animal studies, general human population, $\mathrm{Se}: \mathrm{Hg}$ molar ratios in organisms, $\mathrm{Hg}$ and Se levels in biological samples, the impact of diverse chemical forms of Se on biological/health effects of various chemical forms of $\mathrm{Hg}$ ) and exclusion criteria (the non-English language, data from unpublished studies, methodological issues, special population groups, i.e., infants, children, pregnant women, case-control studies, clinical outcomes, others interaction e.g., synergism). In the end, we chose the one, which included reciprocal action between the 2 elements, and the related effects on the organism, organs and the tissues.

\section{RESULTS}

\section{Possible mechanisms of $\mathrm{Hg}-\mathrm{Se}$ interaction}

Majority of the studies available in the literature and concerning the mechanisms of the $\mathrm{Hg}-\mathrm{Se}$ interaction as well as the potential detoxification processes use animal models. In addition, antagonistic influence of Se on bioaccumulation of $\mathrm{Hg}$ in experimental animals is well known, however, interaction mechanism between these elements in a human body has still remained unexplained [31,32]. Considering interspecies differences in the toxicity of $\mathrm{Hg}$, it is very difficult to unambiguously explain this interaction in a human body. Currently, $\mathrm{Hg}-\mathrm{Se}$ interaction and its bio- 
logical responses in organisms related to their antagonistic reciprocal action still raises a large interest [13,33-35]. In science, it is crucial to understand protective mechanisms against $\mathrm{Hg}$ toxicity. There are several known possible pathways of $\mathrm{Hg}-\mathrm{Se}$ interaction.

\section{Formation of $\mathrm{Hg}-\mathrm{Se}$ as well as $\mathrm{MeHg}-\mathrm{Se}$ compounds}

The above mentioned toxic effect of $\mathrm{Hg}$ at the molecular level is primarily diminished due to the formation of biologically inactive complexes with proteins containing Se, mainly with $\mathrm{SeP}[13,28]$. There is evidence that plasma Se forms complexes with inorganic mercury $(\mathrm{iHg})$, which then combine with SeP [11,13], which in turn prevents accumulation of $\mathrm{Hg}$ in the kidney [36]. Moreover, a bisselenite-methylmercuric, selenocysteinemethylmercury complexes, a cluster of $[(\mathrm{Hg}-\mathrm{Se}) n] m-\mathrm{SeP}$ and onofrite $\left(\mathrm{HgSe}_{\mathrm{x}} \mathrm{S}_{1-} \mathrm{x} ; 0<\mathrm{x} \leq 1\right)$ biomineral, are responsible for the antagonism $\mathrm{Hg}-\mathrm{Se}$ in biological systems at the molecular level [12]. Onofrite compound in a form of nanoclusters is created via glutathione. It is dependent on the $\mathrm{pH}$ and reversibly soluble, thanks to which it plays the largest part in distribution of $\mathrm{Hg}$.

\section{Selenium-aided demethylation of $\mathrm{MeHg}$}

This type of a possible pathway of the reciprocal action has been observed mainly in the liver and kidney in marine mammals and seabirds [37,38], where the highest concentration of $\mathrm{iHg}$ could be observed. Accumulation of $\mathrm{iHg}$ in these organs after exposure to $\mathrm{MeHg}$ may suggest a demethylation process. Additionally, it seems that, the demethylation takes place after a critical threshold value of $\mathrm{MeHg}$ has been reached. Palmisano et al. [39] calculated that threshold concentration of $\mathrm{MeHg}$ in the liver of a dolphin amounted to about $100 \mu \mathrm{g} / \mathrm{g}$ wet weight. Martoja and Berry [38] in their study identified a tiemannite (mineral in a form of mercuric selenide) in the liver of cetaceans as a probable product of demethylation. This stable and inert complex explains the protective effect of Se on $\mathrm{Hg}$.
The latest studies have been performed with regard to the pathway of interaction between $\mathrm{Hg}-\mathrm{Se}$ based on the influence of selenoneine (SeN, Se-containing compound) intake (mainly from fish) on $\mathrm{MeHg}$ accumulation and resulting toxicity. Nevertheless, this mechanism still remains unclear. Selenoneine has a strong antioxidant potential in the redox cycle due to its unique structure of Se atom in the imidazole ring (similar structure to ergothioneine). Yamashita et al. [40,41] showed that, SeN discovered in tuna may remove free radicals which are initiated by MeHg. The potential detofixication mechanism consists in forming a complex between $\mathrm{SeN}$ with $\mathrm{MeHg}$, which then may be incorporated into endosomes and lysosomes. This molecular mechanism is mediated by a selenoneine-specific transporter, organic cations/carnitine transporter-1 (OCTN1). The latest study describes the demethylation process of $\mathrm{Hg}$ in marine fish (black seabream) after Se treatment. Wang et al. [42] showed in their study that not liver but the intestine was the major site for $\mathrm{Hg}-\mathrm{Se}$ interaction. Authors claimed that Se affected elimination of the generated $\mathrm{iHg}$, but not the distribution of $\mathrm{MeHg}$.

\section{Redistribution of $\mathrm{Hg}$ (in the presence of $\mathrm{Se}$ )}

Redistribution of $\mathrm{Hg}$ among various organs, which often takes place from more sensitive to the less critical ones. Transport of $\mathrm{Hg}$ to specific organs and its redistribution depend on binding of $\mathrm{Hg}$ to low molecular weight thiols (sulfur-containing biomolecules: MTs, GSH and albu$\mathrm{min}$ ), that are diffusible and thus, that easily pass through cell membranes. Some studies concern the transport mechanism of $\mathrm{Hg}$ in the body based on the molecular mimicry. Bridges and Zalups [43] define the mechanism of molecular and/or ionic mimicry as the formation of complexes (mainly organo-metal) similar to endogenous biomolecules. Similarity may be structural and/or functional. This way low molecular weight thiols bound to $\mathrm{Hg}$ ions may pass and entry into each cell via the mechanism of molecular mimicry $[44,45]$. Three known conju- 
gates are similar to each other in terms of their chemical structure: the amino acid cystine and the Cys S-conjugate of $\mathrm{iHg}$ (Cys-S-Hg-S-Cys), the amino acid methionine and the cysteine S-conjugate of $\mathrm{MeHg}\left(\mathrm{CH}_{3} \mathrm{Hg}-\mathrm{S}\right.$-Cys $)$ and the homocystine and homocysteine $\mathrm{S}$-conjugate of $\mathrm{iHg}$ (Hcys-S-Hg-S-Hcys) $[43,45,46]$.

A hypothesis assumes that, Se causes the release of bound $\mathrm{iHg}$ to low molecular weight thiols and their diversion to high molecular weight proteins in organs [10,36,47]. Yamamoto [36] showed that, in the presence of $\mathrm{Se}, \mathrm{Hg}$ bound into a high molecular weight complex with selenoprotein $\mathrm{P}$, which seemed to prevent $\mathrm{Hg}$ uptake by the kidneys and therefore, $\mathrm{Hg}$ content in the kidneys of mice was low. García-Sevillano et al. [48] observed a protective effect of Se on $\mathrm{Hg}$ toxicity in blood plasma of mice. The effect results in a decrease of intensity of Se-protein in plasma with $\mathrm{Hg}$ exposure and correlative increases of $\mathrm{Hg}$-albumin that transports $\mathrm{Hg}$ to kidney for excretion. Chen et al. [10] have found that, uptake and binding of $\mathrm{Hg}$ to MT in blood of rats, is then affected by Se which alters $\mathrm{Hg}$ distribution to high molecular weight proteins in the liver, testis and kidneys. However, Se-pretreated rats had an elevated $\mathrm{Hg}$ concentration in their blood and testis but significantly diminished $\mathrm{Hg}$ level in the kidneys. It shows a possible path of detoxification of $\mathrm{Hg}$ in the presence of Se.

\section{Selenium prevention of oxidative stress \\ and of free radicals induced by $\mathrm{Hg}$}

Prevention by means of increasing the Se-dependent enzymes such as: GPx [49] and TrxR [50]. The studies have indicated that $\mathrm{Hg}$ and its compounds may inhibit GPx activity [25,51-53]. Starting from animal models, a number of studies indicate that Se antagonizes Hg-induced toxicity related to the oxidative stress markers and activity of selenoproteins depending on the Se status. Su et al. [35] describe that mercury chloride $\left(\mathrm{HgCl}_{2}\right)$ significantly decreases $(\mathrm{p}<0.05)$ the activity of GSH and superoxide dis- mutase (SOD) and at the same time increases level of the malondialdehyde (MDA) in the liver of rats, the product of lipid peroxidation. After equimolar co-administration of Se and $\mathrm{Hg}$, the MDA level was significantly decreased and SOD activity was increased $(\mathrm{p}<0.05)$. After $\mathrm{Hg}$ administration the content of SOD in kidney significantly decreased ( $p<0.05$ ), in contrast to GSH and MDA. In another study, Grotto et al. [54] showed the possible antigenotoxic effect of Se in rats. After chronic exposure to low levels of MeHg, it revealed GPx activity and DNA lesions in rats. Moreover, a significant and negative correlation was found $(r=-0.559, \mathrm{p}<0.05)$ between GPx activity and DNA damage. Additionally, the authors claimed that Se in concentrations of 2 and $6 \mathrm{mg} / \mathrm{l}$ from drinking water reduced DNA injuries caused by $\mathrm{MeHg}$ exposure, by about 35\% and 40\%, respectively. Methylmercury is toxic and induces pathological changes in the nervous system. A group of researchers of Mori et al. [55] showed a decreased GSH level and GPx activity due to oral administration of an organic form of $\mathrm{Hg}$, contrary to the SOD activity in mitochondria isolated from cerebellum and cerebrum of rats.

According to the research by Zemolin et al. [56] after $\mathrm{MeHg}$ administration, the activity of the antioxidant enzymes glutathione S-transferase (GST), CAT, SOD and glutathione reductase (GR) was increased in the cerebellum of mice. The electron microscopy analysis delivered useful information of mitochondrial ultrastructure in cerebral cortex. Micrographs showed excessive alterations (curved-shaped, elongated or an increase in their volume) and reduction in their number (up to $60 \%$ of reduction) after MeHg-treated mice as compared to controls as well as organoselenium compound (diphenyl diselenide $(\mathrm{PhSe})_{2}$ ) co-administration [57,58]. De Freitas et al. [25] confirmed a decrease in MeHg-induced cerebral oxidative stress by $(\mathrm{PhSe})_{2}$. Diphenyl diselenide in dose $1 \mathrm{mg} / \mathrm{kg} / \mathrm{day}$ and $0.4 \mathrm{mg} / \mathrm{kg} /$ day decreased $\mathrm{MeHg}$ toxicity via its reduction to selenol/selenolate $\left(\mathrm{PhSeH} / \mathrm{PhSe}^{-}\right)$. Then this form 
of $\mathrm{PhSeH} / \mathrm{PhSe}^{-}$could either directly block the pro-oxidative effects of $\mathrm{MeHg}$ due to its thiol-peroxidase activity or form a stable complex with $\mathrm{MeHg}$ that was more easily excreted, simultaneously decreasing $\mathrm{Hg}$ body burden. What is interesting, iSe compound sodium selenite $\left(\mathrm{Na}_{2} \mathrm{SeO}_{3}\right)$ did not protect from $\mathrm{MeHg}$-induced oxidative stress [3].

\section{$\mathrm{Hg}-\mathrm{Se}$ interactions in animals}

Toxicokinetics of $\mathrm{Hg}$ has been well described in octopus [59], fish [60,61], birds [62], mice [3,5,36,48,63,64], rats $[6,35,44,47,54,65,66]$, rabbits [7,49], poultry [67], dolphins [68] and so forth. Over 50 years ago, numerous investigations attempted to describe $\mathrm{Hg}-\mathrm{Se}$ interaction in animals. Parizek and Ostadalova [69] and Parizek et al. [70] described studies that found inhibitive effects of Se on the toxicity of $\mathrm{Hg}$ in rats. A series of experiments showed different percentage of surviving rats after injection of salt of $\mathrm{iHg}$ in a dose of $0.02 \mathrm{mmole} \mathrm{HgCl}_{2} / \mathrm{kg}$ body weight and after injection of the salt of $\mathrm{iHg}$ in the same dose and injection of $\mathrm{Na}_{2} \mathrm{SeO}_{3}$ in a dose of $0.03 \mathrm{mmole} / \mathrm{kg}$ body weight $1 \mathrm{~h}$ later. The percentages of surviving rats were: $100 \%(\mathrm{iHg})$ and $97.5 \%(\mathrm{Hg}-\mathrm{Se})$ on the second day, and $3.3 \%(\mathrm{iHg})$ and $97.5 \%(\mathrm{Hg}-\mathrm{Se})$ on the seventh day. Subsequent experiments in rats [65,71] claimed that Se prevented Hg-induced intestinal necrosis. As a consequence, Se decreased mortality.

Many researchers investigated the $\mathrm{Hg}-\mathrm{Se}$ interaction to be the most effective when these elements (mainly in the form of $\mathrm{Na}_{2} \mathrm{SeO}_{3}$ and $\mathrm{HgCl}_{2}$ ) were co-administrated in equimolar ratio $[47,65,69]$. Authors have claimed that, only a correct chemical form of $\mathrm{Hg}$ and $\mathrm{Se}$ and their concentrations may determine whether a potential protective effect appears. Considering $\mathrm{Hg}-\mathrm{Se}$ interaction, $\mathrm{Hg}$ is not harmful to human health if the molar ratio of Se:Hg meets the defined criteria. Selenium will exert its protective action against $\mathrm{Hg}$ toxicity when the molar ratio approaches or exceeds 1 . When Se:Hg molar ratio is below 1 more toxic effect is visible. What is more, the co-exposure of Se and $\mathrm{Hg}$ antagonistically diminishes each other's toxic effects (being in agreement with outcomes of Peterson et al. [72], Li et al. [5]). This statement may show that toxic effects of $\mathrm{Hg}$ are mitigated by Se but only when $\mathrm{Se}: \mathrm{Hg}$ molar ratios is $\geq 1$.

Liao et al. [60] showed opposing results in medaka fish, who claimed that after co-administration of $\mathrm{MeHg}: \mathrm{Se}$ in molar ratio about 1 , the interaction between $\mathrm{MeHg}: \mathrm{Se}$ gave a limited protection against toxicity of both elements. According to Burger et al. [73] the Se:Hg molar ratio in saltwater fish decreased along with the size of the fish species, decreased with the Hg levels, and within a fish species. Comparing the interspecific and intraspecific variation in Se:Hg molar ratios, the authors claimed that in the interspecific variation the mean $\mathrm{Se}: \mathrm{Hg}$ ratio was negatively correlated with the mean $\mathrm{Hg}$ levels (the mean total fish length was not found significantly correlated). The intraspecific differences showed that fish occurring in the North Pacific (dolly varden) had the ratio that was positively correlated with its length and weight and the halibut had the ratio that was negatively correlated with its length and positively correlated with its weight. Selenium does not show protective effects against $\mathrm{Hg}$ toxicity, when the increased fish size is tantamount to a decreased molar ratio. The Hg:Se molar ratio in nearly all marine fish was less than 1 , in marine mammals it was 16:1 [74].

Beijer and Jernelöv [74] showed that increased $\mathrm{Hg}$ retention caused by Se occurred in the marine environment. It may cause the incremental increase in concentration of $\mathrm{Hg}$ and/or Se at each level of a food chain, namely biomagnifications and thus, the higher burden in organism. This might counteract the positive effect of a decreased intoxication. Branco et al. [75] claimed that co-administration of Se and $\mathrm{Hg}$ and thus mutual $\mathrm{Hg}-\mathrm{Se}$ interaction in exposed fish may protect organism (juvenile zebraseabream) against $\mathrm{Hg}$-induced toxicity but this protection is tissue-specific and it depends on the examined form 
of $\mathrm{Hg}$ and the target organ. Moreover, an accumulation of $\mathrm{Hg}$ was considerably lower when exposure to $\mathrm{MeHg}$ and exposure to Se were simultaneous.

Fang [76] showed different efficiency of Se compounds in $\mathrm{Hg}$ toxicity in rats. Iwata et al. [77] noticed the redistribution of $\mathrm{Hg}$ in the presence of Se, only when administering $\mathrm{Se}^{4+}$ and $\mathrm{MeHg}$ to rats was concurrent. Iwata and co-authors showed that $\mathrm{Se}^{4+}$ decreased the amount of MeHg in organs such as: liver, kidneys, brain, heart, and in blood after a week of exposure, in comparison with the high initial concentration of MeHg. Observations of other authors $[10,49]$ of the above studies led to the conclusion that there was a reduction of $\mathrm{Hg}$ concentration in kidneys and liver and increase of it in other tissues e.g., muscles. Jureša et al. [78] found that accumulation of $\mathrm{Hg}$ decreased in kidneys and increased in liver after concurrent administration of $\mathrm{HgCl}_{2}$ and $\mathrm{Na}_{2} \mathrm{SeO}_{3}$. Diminished level of excretion of $\mathrm{Hg}$ in urine $(\mathrm{Hg}-\mathrm{U})$ is due to the presence of $\mathrm{Se}^{4+}$. Lailson-Brito et al. [27] showed a high and positive correlation $(p<0.05)$ between hepatic molar concentrations of $\mathrm{Hg}$ and $\mathrm{Se}$, which was confirmed by the Se-mediated $\mathrm{MeHg}$ detoxification process in dolphins.

Bjerregaard et al. [79,80] showed that Se adjusted the biokinetics of $\mathrm{Hg}$ through increasing $\mathrm{Hg}$ retention in some aquatic mammals but decreasing $\mathrm{MeHg}$ retention in fish. The authors claimed that Se which occurred naturally in marine food chains (the lower trophic level) could play a key role as a main modifier of $\mathrm{MeHg}$ accumulation at these levels, thereby also potentially affects biomagnification of $\mathrm{MeHg}$ toward the higher trophic levels in the aquatic food chains. Naganuma and Imura [49,81] have explored $\mathrm{Hg}-\mathrm{Se}$ in vitro interaction in rabbits. Their studies have shown that the elements may form a bis(methylmercuric)selenide complex in rabbit blood as a product of $\mathrm{MeHg}$ and $\mathrm{Se}^{4+}$. In plasma and erythrocytes most $\mathrm{Hg}^{2+}$ and $\mathrm{Se}^{4+}$ were found in high-molecular weight substance(s), their molar ratio was 1:1 and they hardly passed erythrocytes membrane. The $\mathrm{Hg}$ and Se incorpo- rated to these substances were found in stroma-free hemolysate but not in plasma.

By creating biologically inactive complexes (Hg-Se complex) it increases the co-excretion [34]. We can describe 2 potential biological effects of $\mathrm{Hg}$ and Se exposure: 1. In the case of a specific concentration of $\mathrm{Hg}$ and increasing concentration of $\mathrm{Se}$, first $\mathrm{Hg}$ toxicity is reduced and then Se deficiency is alleviated and that eventually leads to Se toxicity.

2. In the case of a specific concentration of Se and increasing concentration of $\mathrm{Hg}$, first toxicity of Se decreases, then Se deficiency occurs until $\mathrm{Hg}$ toxicity finally takes place [12]. Moreover, the authors notice that optimal conditions for marine mammals (Se:Hg molar ratio of 1:1) occur in the Se deficiency regions, as $\mathrm{Se}$ is bound to $\mathrm{Hg}$ and thus, is not bioavailable. Organic forms of Se, like selenomethionine (SeMet) and selenocysteine (SeCys) were more effective than inorganic forms $\left(\mathrm{Se}^{4+}\right.$ and $\left.\mathrm{Se}^{6+}\right)$, which is inverse of the Sharma and Davis [82] results in goldfish. Similar results to those of Sharma were confirmed by Magos et al. [6] and 30 years later by Bjerregaard et al. [79]. Magos revealed that $\mathrm{Se}^{4+}$ diminished renotoxicity of $\mathrm{iHg}$. Moreover, the authors claimed that biological Se had different effect from $\mathrm{Se}^{4+}$. Formation of $\mathrm{Hg}-\mathrm{Se}$ complexes decreased in the following order: $\mathrm{Se}^{4+}>$ SeMet $>$ biological Se. Fang [76] stated that after co-administration in equimolar ratio the efficiency of $\mathrm{Se}$ on $\mathrm{Hg}$ elimination in kidney decreased in the following order: SeMet (the most effective) $>$ SeCys $>\mathrm{Se}^{6+}>\mathrm{Se}^{4+}$ (the least effective). In the study of Bjerregaard et al. [79] pre-administration of dietary $\mathrm{Se}^{4+}$, SeMet and SeCys to freshwater fish (goldfish and zebrafish) increased elimination of $\mathrm{MeHg}$, in contrast to iHg. Moreover, higher Se concentration diminished retention of $\mathrm{MeHg}$ in a dose dependent manner. In conclusion, Bjerregaard has claimed that Se concentration in aquatic food chain may affect $\mathrm{Hg}$ contamination along the food chain. Selenite as well as organic selenium forms (SeCys and SeMet) increase elimination of $\mathrm{Hg}$ from shrimps. 
Selenate does not induce a more readily elimination [80]. Above interactions are related to $\mathrm{Se}$ and $\mathrm{Hg}$ concentration and their forms, which is summarized in the Table 1.

\section{$\mathrm{Hg}-\mathrm{Se}$ interactions in humans}

The holistic overview of $\mathrm{Hg}-\mathrm{Se}$ relationships, where Se plays direct and/or indirect (through mainly selenoproteins) role is a well-known topic among many scientists. Data on the occurrence of correlation between metabolism of $\mathrm{Hg}$ and expression of selenoproteins in the occupationally (elemental $\mathrm{Hg}$ vapor) and environmentally (organic form of $\mathrm{Hg}$ ) exposed people is still limited [33,89-91]. Studies on humans concerning dysfunction of cellular redox system, disruption of the glutathione system and system-related enzymes glutathione-S-transferase (GST), TrxR and glutamate cysteine ligase (GCL) by exposure to $\mathrm{Hg}$ are inadequate.

Kobal et al. [89] investigated the relationship between occupational exposure to $\mathrm{Hg}^{0}$ and GSH system: erythrocyte GSH level, enzymatic activity of GPx and activities of CAT and GR. Although there were no statistically significant differences between the mean GPx activity, levels of total GSH, oxidized disulphide glutathione (GSSG) and GSH/GSSG ratio between the studied miners and the control group. The mean concentration of reduced GSH was significantly higher in the miners $(13.64 \pm 3.71 \mathrm{mmol} / \mathrm{g} \mathrm{Hb})$ in comparison with the retired miners $(9.64 \pm 1.45 \mathrm{mmol} / \mathrm{g} \mathrm{Hb})$ as well as with the control group (11.68 $\pm 2.66 \mathrm{mmol} / \mathrm{g} \mathrm{Hb})$, $(\mathrm{p}<0.05)$. Moreover, the retired miners had the lowest $(\mathrm{p}<0.05)$ level of the mean total GSH. The mean GR and CAT activity in erythrocytes in the miners was significantly higher $(p<0.05)$ than in the retired miners and in the control group. In the end, Kobal showed a positive correlation between GSSG and present $\mathrm{Hg}-\mathrm{U}$ excretion $(r=0.41$, $\mathrm{p}=0.001)$ in the retired miners.

The relationships between $\mathrm{Hg}^{0}$ exposure and activities of SOD and GPx in erythrocytes of the workers from a chloroalkali plant were examined by Bulat et al. [92]. Mercury-exposed individuals had significantly lower activities of GPx and SOD when compared to the control group (GPx: 9.05 $\pm 7.52 \mathrm{IU} / \mathrm{g} \mathrm{Hb}, \mathrm{p}<0.001$, SOD: $1280.7 \pm 132.3 \mathrm{IU} / \mathrm{g} \mathrm{Hb}, \mathrm{p}<0.006$ and GPx:

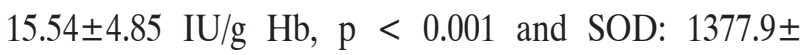
$207.5 \mathrm{IU} / \mathrm{g} \mathrm{Hb}, \mathrm{p}<0.006)$. Similar results occurred in the study by Samir and Aref [93], where dental personnel had GPx and SOD activity in blood significantly decreased $(\mathrm{p}<0.001)$ in comparison with the control group. Additionally, these authors showed an inverse significant association between $\mathrm{Hg}-\mathrm{U}$ and both GPx and SOD activity in blood $(\mathrm{r}=-0.668, \mathrm{p}<0.001$ and $\mathrm{r}=-0.670, \mathrm{p}<0.001$, respectively). What is more, dental staff had significantly higher ( $p<0.001$ ) concentrations of albumin and $\alpha 1$ microgloblin in urine (the biomarkers of early renal effects), which means that occupational exposure to $\mathrm{Hg}^{0}$ diminished activity of antioxidant enzymes and that their effect may influence a possible mechanism of renal disorders.

The study of Chen et al. [33] is another confirmation that $\mathrm{Se}$ is reversing of oxidative stress including $\mathrm{Hg}$-induced inhibition of the enzymes of GSH metabolism. The occupationally $\mathrm{Hg}^{0}$-exposed people who worked in mining, in Guizhou (China), contrary to the control group, had a statistically significantly increased $(p<0.05)$ concentration of MDA and SeP in serum as well as activity of GPx in serum. Along with the increase, the authors observed an increase of Se concentration in serum (Se-S) and a decreased production of ROS. A strong positive correlation between concentrations of $\mathrm{Se}$ in urine $(\mathrm{Se}-\mathrm{U})$ and $\mathrm{Hg}-\mathrm{U}$ $(\mathrm{R}=0.625, \mathrm{p}<0.001)$ but not between Se-S and $\mathrm{Hg}$ in serum $(\mathrm{Hg}-\mathrm{S})$ as well as a higher concentration of Se-S were also investigated in the study by Chen et al. [33] in the case of workers compared to the control group.

Additionally, a significantly higher $(p<0.05)$ concentration of $\mathrm{Hg}$ in $\mathrm{SeP}$ in serum occurred among the $\mathrm{Hg}^{0}$-exposed subjects compared to the control group, where the SeP-containing fraction bound more Hg. The molar 


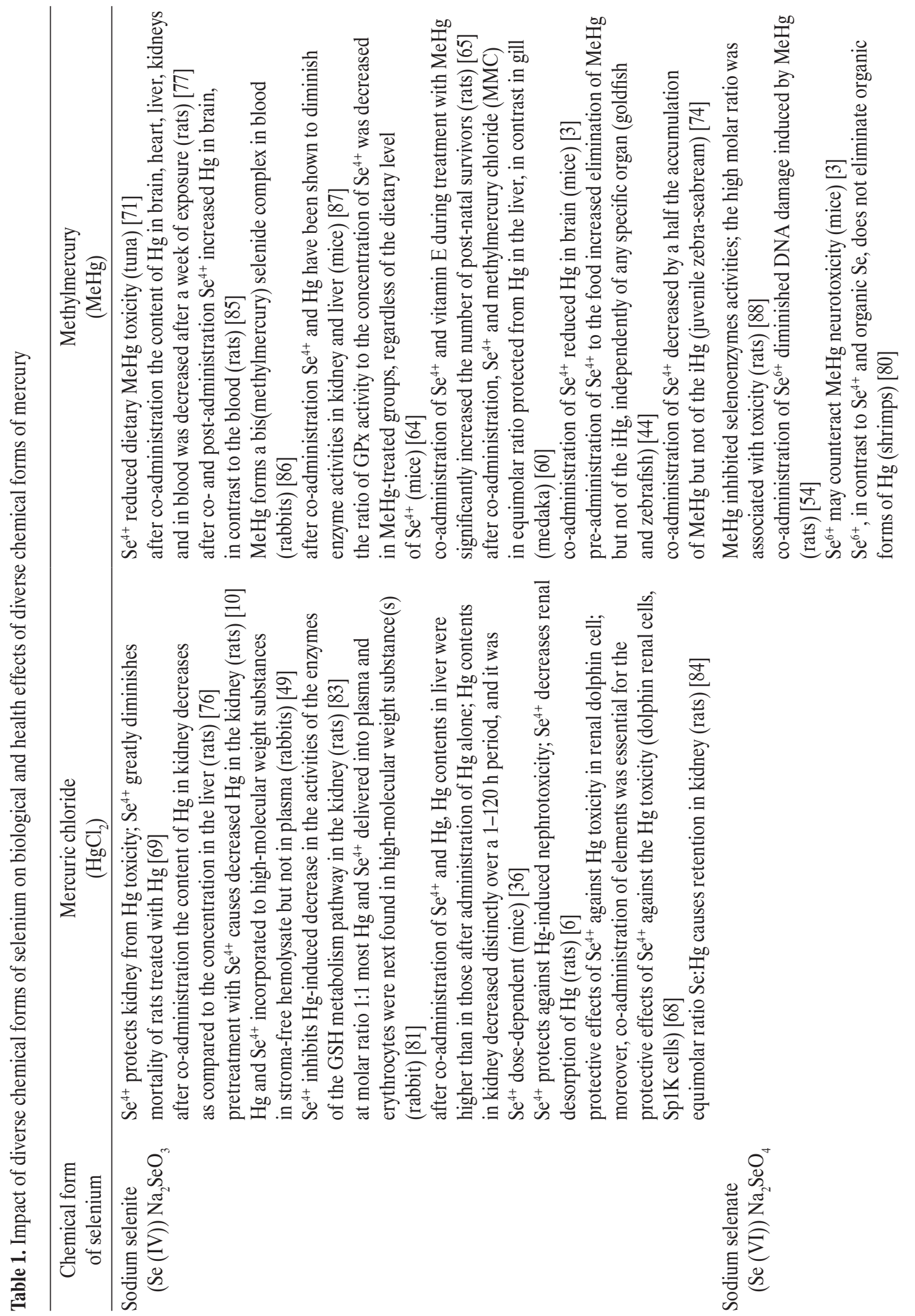




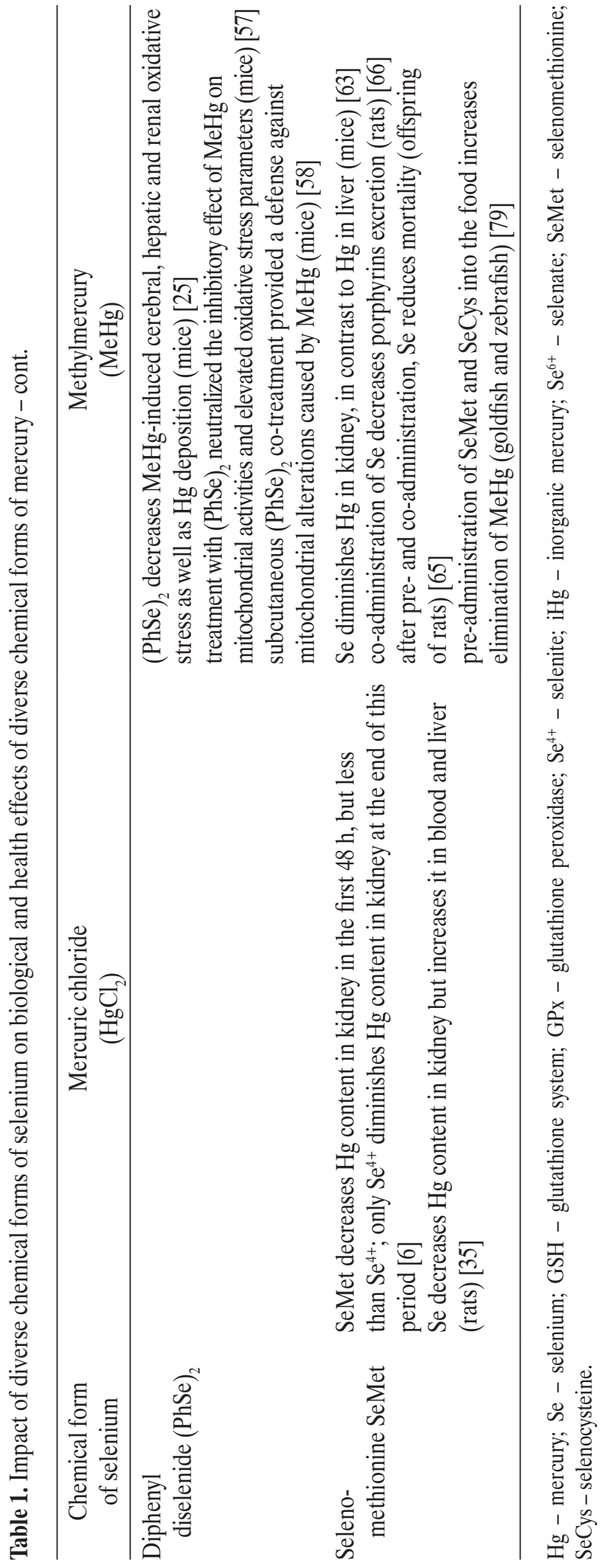

ratio $\mathrm{Se}: \mathrm{Hg}$ in SeP was significantly lower $(\mathrm{p}<0.05)$ in the exposed group $7.8 \pm 3.1$ as compared to the control group $535 \pm 216$. All these results indicate a strong $\mathrm{Hg}-\mathrm{Se}$ reciprocal action leading to the induction of antioxidant defense mechanisms. An increased synthesis of SeP induced by a high level of Se caused a mechanism that prevented accumulation of $\mathrm{Hg}$ in the body due to its bounding with SeP in blood.

In people from Brasilian Amazon environmentally exposed to $\mathrm{Hg}$, a negative linear correlation $(\mathrm{p}<0.05)$ between the activity of GPx, concentration of GSH and activity of CAT in blood samples and concentration of $\mathrm{Hg}$ in the whole blood (Hg-B) [19] was observed.

\section{Impact of genetic susceptibility}

\section{on mercury metabolism}

Since a configuration of genetic information of the human body determines the situation in which some of the genes are expressed, while other genes stay inactive, eukaryotic gene expression may be controlled and modulated/regulated from transcriptional initiation, to RNA processing and to the posttranslational modification of proteins. In a response to a disturbance of the environment caused by $\mathrm{Hg}$ exposure, the gene expression levels directly relate to suitable protein levels, thus, proteins activity and their function may be altered by $\mathrm{Hg}$. More and more scientists are trying to understand the toxicologically relevant interaction between $\mathrm{Hg}$ and Se with an emphasis on pathway from gene expression to molecular processes. Humans have individual sensitivity to $\mathrm{Hg}$ and their inter-individual variability may indicate the influence of genetic regulatory mechanisms (Gundacker et al. [94]).

Numerous studies have reported that genetic polymorphism: glutathione S-transferase (GST), metallothionein $(M T)$ and selenoprotein $\mathrm{P}$ (SEPP1) may be associated with the metabolism of $\mathrm{Hg}$ [90,94-96]. Glutathione S-transferase belongs to the family of polymorphism enzymes with the predisposition to accumulation and elimi- 
nation of $\mathrm{Hg}$ in the urine or its retention may be indirectly dependent on GST in cytosol. Glutathione S-transferase is a group of phase II enzymes involved in the biotransformation of coupling heavy metal ions with reduced GSH. Studies have shown ethnic differences in minor allele frequencies (MAFs) within the GST. Deletion polymorphism for GSTT1 gene (41\% MAF for Caucasian population according to HapMap base) is associated with the absence of the gene-encoded enzyme but not only GSTT1 deletion polymorphism but also nonsynonymous polymorphism of GSTP1 gene (rs1695 Ise105Val) play a role in $\mathrm{Hg}$ metabolism [97].

Minor allele frequencies of the above mentioned polymorphism similar to that of Caucasian populations (HapMap base) amounted to $13 \%$. Genetic polymorphisms in the selected genes may determine the inter-individual differences in sensitivity response to the environmental and occupational exposure to $\mathrm{MeHg}$ and $\mathrm{Hg}^{0}$ (gene-environment interactions). Schläwicke-Engström et al. [98] presented the results suggesting the modifying effects of polymorphism of GSTP1 and gene encoding of gammaglutamylcysteine ligase (GCLM) on metabolism and retention of $\mathrm{MeHg}$ in environmental exposure in Swedish population. Authors have examined that GSTP1 polymorphism may exhibit a higher concentration $\mathrm{Hg}$ in erythrocytes. Gundacker et al. [94] showed the concentration of Hg-B for genotype GSTT1+ was negatively correlated with GSTM1+ among a group of students from Austrian population.

It is also known, that selenoproteins (i.e., SeP and GPx) may affect toxicokinetics of $\mathrm{Hg}$ and alter metabolism of $\mathrm{Hg}$. Chen et al. [33] showed that miners in Guizhou (China) with occupational exposure to $\mathrm{Hg}$ presented increased expression of SEPP1 gene. This may suggest ability to bind $\mathrm{Hg}$ by selenocysteine. Polymorphism in the SEPP1 gene (rs7579) is associated with a change of cytosine $(\mathrm{C})$ to thymine $(\mathrm{T})$ in the 3'UTR untranslated region. TT homozygotes may lead to an increase in Hg-binding ability [99].
Goodrich et al. [90] showed inter-individual variability among dentists from Michigan. T allele modified an association between sources of exposure to $\mathrm{Hg}$ and concentration of $\mathrm{Hg}-\mathrm{U}$. In the case of a higher exposure to $\mathrm{Hg}$, the CT or TT genotype, in genotype-by-amalgam interactions, was characterized by a higher urinary excretion of $\mathrm{Hg}$ than the CC homozygotes. The authors also claim that genetic polymorphisms in selenoproteins and glutathione-related genes may influence excretion of $\mathrm{Hg}-\mathrm{U}$ (polymorphisms significantly associated - GSTT1 deletion) and hair or Hg retention (GSTP1-105, GSTP1-114, GSS 5') or both (SEPP1 3' UTR) following exposures to $\mathrm{Hg}^{0}$ (dental amalgams) and $\mathrm{MeHg}$ (fish consumption). Moreover, the study of Goodrich et al. [90] have indicated that a higher expression of SEPP1 in dentists with genopyte T (CT or TT) may influence Hg binding and following distribution to various tissues.

Metallothioneins are specific proteins which contain cysteine groups, to which $\mathrm{Hg}$ preferably binds. Since they play a protective role against nephrotoxic effects of $\mathrm{Hg}$, they allow its transport and excretion. Exposure to $\mathrm{Hg}$ affects induction of MTs synthesis in the kidneys. The study of Thornalley and Vasak [100] reveals that MTs may be involved in the response to increasing oxidative stress. Therefore, genetic polymorphisms in MT genes may affect the inter-individual differences in $\mathrm{Hg}$ exposure-biomarker levels [101]. People with the MT1M (rs2270836) AA genotype or the MT2A (rs10636) CC genotype are characterized by lower concentration $\mathrm{Hg}-\mathrm{U}$ in comparison with GG homozygote levels. In addition, Wang et al. [101] show that genetic polymorphism in MT2A and MT1A have also a modifying effect on the levels of early renal dysfunction biomarkers. Homozygote variant AA genotype for MT1A (rs11076161) showed the highest activity of NAG and concentration of $\beta_{2} \mathrm{M}$ in urine. These MTs were selected with polymorphism in 3' UTR: MT2A $\mathrm{G}>\mathrm{C}$ (rs10636) (30\% for MAF according to Entrez SNP base) and MT1M G > A (rs2270836) (15\% for MAF). 
Without a doubt, we cannot forget about the individual susceptibility to the toxic effects of $\mathrm{Hg}$, either. It should be noted that $\mathrm{Hg}$ affects all types of tissues and may affect many organs but the response of the organ/organism (including age, sex, ethnicity) to $\mathrm{Hg}$ depends on the individual genetic susceptibility to $\mathrm{Hg}$ metabolism $[94,102]$ and the workable detoxification process in a human body. $\mathrm{Nu}-$ merous studies have reported that genetic variations such as: GST, MT and SEPP1 may be associated with metabolism of $\mathrm{Hg}[90,94-96,101]$. It is considered that the predisposition to accumulation and elimination of $\mathrm{Hg}$ in the urine or its retention may be indirectly dependent on the proteins and other molecules of major biological significance.

\section{CONCLUSIONS}

Summing up, this paper has reviewed interactions between Se and $\mathrm{Hg}$ in animals and humans. The majority of studies carried out using animal models show that concurrent administration of $\mathrm{Hg}$ and $\mathrm{Se}$ in diverse chemical forms at supraphysiological concentrations reduces toxicity of $\mathrm{Hg}$ in the case of acute as well as chronic exposure. Treatment with high concentrations of $\mathrm{Hg}$ and Se provides short-term and observable effects, where such an interaction most probably counteracts the adverse effects (neurotoxic and renotoxic) of exposure to $\mathrm{Hg}$. However, human studies on $\mathrm{Hg}-\mathrm{Se}$ reciprocal actions are not consistent. It is suggested that the $\mathrm{Hg}-\mathrm{Se}-$ protein complex plays a role in restraining toxicity of $\mathrm{iHg}$ as well as $\mathrm{MeHg}$ by binding $\mathrm{Hg}$ to prevent it from reaching target tissues. Selenium plays its biological function through selenoproteins, in the case of which the highly reactive selenol group may bind to $\mathrm{Hg}$ as well as through antioxidative properties that cause a direct reduction of ROS levels triggered by $\mathrm{Hg}$.

\section{REFERENCES}

1. Lim HE, Shim JJ, Lee SY, Lee SH, Kang SY, Jo JY, et al. Mercury inhalation poisoning and acute lung injury. Korean J Intern Med. 1998;13(2):127-30, https://doi.org/10.3904/kj im.1998.13.2.127.
2. Akbal A, Yllmaz H, Tutkun E, Köş DM. Aggravated neuromuscular symptoms of mercury exposure from dental amalgam fillings. J Trace Elem Med Biol. 2014;28(1):32-4, https://doi.org/10.1016/j.jtemb.2013.09.005.

3. Glaser V, Nazari EM, Müller YM, Feksa L, Wannmacher CM, Rocha JB, et al. Effects of inorganic selenium administration in methylmercury induced neurotoxicity in mouse cerebral cortex. Int J Dev Neurosci. 2010;28(7):6317, https://doi.org/10.1016/j.ijdevneu.2010.07.225.

4. Roos PM, Dencker L. Mercury in the spinal cord after inhalation of mercury. Basic Clin Pharmacol Toxicol. 2012;111(2):126-32, https://doi.org/10.1111/j.1742-7843.20 12.00872.x.

5. Li X, Yin D, Li J, Wang R. Protective effects of selenium on mercury induced immunotoxic effects in mice by way of concurrent drinking water exposure. Arch Environ Contam Toxicol. 2014;67(1):104-14, https://doi.org/10.1007/s00244014-0001-2.

6. Magos L, Clarkson TW, Sparrow S, Hudson AR. Comparison of the protection given by selenite, selenomethionine and biological selenium against the renotoxicity of mercury. Arch Toxicol. 1987;60(6):422-6, https://doi.org/10.1007/BF 00302384.

7. Zalups RK. Renal accumulation and intrarenal distribution of inorganic mercury in the rabbit: Effect of unilateral nephrectomy and dose of mercuric chloride. J Toxicol Environ Health. 1991;33(2):213-28, https://doi.org/10.1080/ 15287399109531519.

8. Park K, Mozaffarian D. Omega-3 fatty acids, mercury, and selenium in fish and the risk of cardiovascular diseases. Curr Atheroscler Rep. 2010;12(6):414-22, https://doi.org/ 10.1007/s11883-010-0138-z.

9. Yoshizawa K, Rimm EB, Morris JS, Spate VL, Hsieh CC, Spiegelman D, et al. Mercury and the risk of coronary heart disease in men. N Engl J Med. 2002;347(22):1755-60, https:// doi.org/10.1056/NEJMoa021437.

10. Chen RW, Whanger PD, Fang SC. Diversion of mercury binding in rat tissues by selenium: A possible mechanism 
of protection. Pharmacol Res Commun. 1974;6(6):571-9, https://doi.org/10.1016/S0031-6989(74)80006-8.

11. Gailer J, George GN, Pickering IJ, Madden S, Prince RC, Yu EY, et al. Structural basis of the antagonism between inorganic mercury and selenium in mammals. Chem Res Toxicol. 2000;13(11):1135-42, https://doi.org/10.1021/ tx000050h.

12. Khan MA, Wang F. Reversible dissolution of glutathione-mediated $\operatorname{HgSe}(\mathrm{x}) \mathrm{S}(1-\mathrm{x})$ nanoparticles and possible significance in $\mathrm{Hg}-\mathrm{Se}$ antagonism. Chem Res Toxicol. 2009;22(11):1827-32, https://doi.org/10.1021/tx900234a.

13. Suzuki KT, Sasakura C, Yoneda S. Binding sites for the (Hg-Se) complex on selenoprotein P. Biochim Biophys Acta. 1998;1429(1):102-12, https://doi.org/10.1016/S0167-48 38(98)00221-0.

14. El-Safty IA, Shouman AE, Amin NE. Nephrotoxic effects of mercury exposure and smoking among Egyptian workers in a fluorescent lamp factory. Arch Med Res. 2003;34(1):50-5, https://doi.org/10.1016/S0188-4409(02)00462-9.

15. Jarosińska D, Horvat M, Sällsten G, Mazzolai B, Dąbkowska B, Prokopowicz A, et al. Urinary mercury and biomarkers of early renal dysfunction in environmentally and occupationally exposed adults: A three-country study. Environ Res. 2008;108(2):224-32, https://doi.org/10.1016/j.envres.2008.06.005.

16. Bernard AM, Vyskocil AA, Mahieu P, Lauwerys RR. Assessment of urinary retinol-binding protein as an index of proximal tubular injury. Clin Chem. 1987;33(6):775-9.

17. Ralston NVC, Raymond LJ. Dietary selenium's protective effects against methylmercury toxicity. Toxicology. 2010;278(1):112-23, https://doi.org/10.1016/j.tox.2010. 06.004 .

18. Kobal AB, Horvat M, Prezelj M, Briski AS, Krsnik M, Dizdarevic T, et al. The impact of long-term past exposure to elemental mercury on antioxidative capacity and lipidperoxidation in mercury miners. J Trace Elem Med Biol. 2004;17(4):261-74, https://doi.org/10.1016/S0946-672 $\mathrm{X}(04) 80028-2$.
19. Grotto D, Valentini J, Fillion M, Passos CJ, Garcia SC, Mergler D, et al. Mercury exposure and oxidative stress in communities of the Brazilian Amazon. Sci Total Environ. 2010;408(4):806-11, https://doi.org/10.1016/j.scitotenv. 2009.10.053.

20. Grotto D, Vicentini J, Angeli JP, Latorraca EF, Monteiro PA, Barcelos GR, et al. Evaluation of protective effects of fish oil against oxidative damage in rats exposed to methylmercury. Ecotoxicol Environ Saf. 2011;74(3):487-93, https://doi.org/10.1016/j.ecoenv.2010.10.012.

21. Pinheiro MC, Macchi BM, Vieira JL, Oikawa T, Amoras WW, Guimarães GA, et al. Mercury exposure and antioxidant defenses in women: A comparative study in the Amazon. Environ Res. 2008;107(1):53-9, https://doi. org/10.1016/j.envres.2007.08.007.

22. Cebulska-Wasilewska A, Panek A, Żabiński Z, Moszczyński P, Au WW. Occupational exposure to mercury vapour and genotoxicity and DNA repair. Mutat Res. 2005;586:102-14, https://doi.org/10.1016/j.mrgentox.2005.06.009.

23. Hossain MB, Barregård L, Sallsten G, Broberg K. Cadmium, mercury, and lead in kidney cortex are not associated with urinary 8-oxo-7,8-dihydro-2'-deoxyguanosine (8-oxodG) in living kidney donors. Int Arch Occup Environ Health. 2014;87(3):315-22, https://doi.org/10.1007/s00420013-0863-z.

24. Loft S, Høgh Danielsen P, Mikkelsen L, Risom L, Forchhammer L, Møller P. Biomarkers of oxidative damage to DNA and repair. Biochem Soc Trans. 2008;36(5):1071-6, https://doi.org/10.1042/BST0361071.

25. De Freitas AS, Funck VR, Rotta Mdos S, Bohrer D, Morschbacher V, Puntel RL, et al. Diphenyl diselenide, a simple organoselenium compound, decreases methylmercury induced cerebral, hepatic and renal oxidative stress and mercury deposition in adult mice. Brain Res Bull. 2009;79(1): 77-84, https://doi.org/10.1016/j.brainresbull.2008.11.001.

26. Kurokawa S, Berry MJ. Selenium. Role of the essential metalloid in health. Met Ions Life Sci. 2013;13:499-534, https:// doi.org/10.1007/978-94-007-7500-8_16. 
27. Lailson-Brito J, Cruz R, Dorneles PR, Andrade L, Azevedo Ade F, Fragoso AB, et al. Mercury-selenium relationships in liver of Guiana dolphin: The possible role of Kupffer cells in the detoxification process by Tiemannite formation. PLoS One. 2012;7(7):e42162, https://doi.org/10.1371/journal. pone. 0042162.

28. Burk RF, Hill KE. Selenoprotein P: An extracellular protein with unique physical characteristics and a role in selenium homeostasis. Annu Rev Nutr. 2005;25:215-35, https://doi. org/10.1146/annurev.nutr.24.012003.132120.

29. Chen J, Berry MJ. Selenium and selenoproteins in the brain and brain diseases. J Neurochem. 2003;86(1):1-12, https:// doi.org/10.1046/j.1471-4159.2003.01854.x.

30. Moher D, Liberati A, Tetzlaff J, Altman DG; The PRISMA Group. Preferred reporting items for systematic reviews and metaanalyses: The PRISMA statement. PLoS Med. 2009;6(7):e1000097, https://doi.org/10.1371/journal. pmed.1000097.

31. Gailer J. Arsenic-selenium and mercury-selenium bonds in biology. Coord Chem Rev. 2007;251(1-2):234-54, https:// doi.org/10.1016/j.ccr.2006.07.018.

32. Yang D, Yu-Wei C, Gunn JM, Belzille N. Selenium and mercury in organisms: Interactions and mechanisms. Environ Rev. 2008;16:71-92, https://doi.org/10.1139/A08-001.

33. Chen C, Yu H, Zhao J, Li B, Qu L, Liu S, et al. The roles of serum selenium and selenoproteins on mercury toxicity in environmental and occupational exposure. Environ Health Perspect. 2006;114(2):297-301, https://doi.org/10.1289/ehp.7861.

34. Falnoga I, Tusek-Znidaric M. Selenium-mercury interactions in man and animals. Biol Trace Elem Res. 2007;119(3): 212-20, https://doi.org/10.1007/s12011-007-8009-3.

35. Su L, Wang M, Yin ST, Wang HL, Chen L, Sun LG, et al. The interaction of selenium and mercury in the accumulations and oxidative stress of rat tissues. Ecotoxicol Environ Saf. 2008;70(3):483-9, https://doi.org/10.1016/j.eco env.2007.05.018.

36. Yamamoto I. Effect of various amounts of selenium on the metabolism of mercuric chloride in mice. Biochem
Pharmacol. 1985;34(15):2713-20, https://doi.org/10.1016/ 0006-2952(85)90572-6.

37. Bełdowska M, Falkowska L. Mercury in marine fish, mammals, seabirds, and human hair in the coastal zone of the southern Baltic. Water Air Soil Pollut. 2016;227:52, https:// doi.org/10.1007/s11270-015-2735-5.

38. Martoja R, Berry J-P. Identification of Tiemannite as a probable product of demethylation of mercury by selenium in cetaceans. A complement to the scheme of the biological cycle of mercury. Vie Milieu Paris. 1980;30(1):7-10.

39. Palmisano F, Cardellicchiob N, Zambonin PG. Speciation of mercury in dolphin liver: A two-stage mechanism for the demethylation accumulation process and role of selenium. Mar Environ Res. 1995;40(2):109-21, https:/doi. org/10.1016/0141-1136(94)00142-C.

40. Yamashita Y, Yabu T, Yamashita M. Discovery of the strong antioxidant selenoneine in tuna and selenium redox metabolism. World J Biol Chem. 2010;1(5):144-50, https://doi. org/10.4331/wjbc.v1.i5.144.

41. Yamashita M, Yamashita Y, Suzuki T, Kani Y, Mizusawa N, Imamura S, et al. Selenoneine, a novel selenium-containing compound, mediates detoxification mechanisms against methylmercury accumulation and toxicity in zebrafish embryo. Mar Biotechnol (NY). 2013;15(5):559-70, https://doi.org/10.1007/s10126-0139508-1.

42. Wang X, Wang W-X. Selenium induces the demethylation of mercury in marine fish. Environ Pollut. 2017;231(Pt 2): 1543-51, https://doi.org/10.1016/j.envpol.2017.09.014.

43. Bridges CC, Zalups RK. Molecular and ionic mimicry and the transport of toxic metals. Toxicol Appl Pharmacol. 2005;204(3):274-308, https://doi.org/10.1016/j.taap. 2004.09.007.

44. Bridges CC, Bauch C, Verrey F, Zalups RK. Mercuric conjugates of cysteine are transported by the amino acid transporter system b0,+: Implications of molecular mimicry. J Am Soc Nephrol. 2004;15(3):663-73, https://doi.org/10.1097/01. ASN.0000113553.62380.F5. 
45. Clarkson TW. Molecular and ionic mimicry of toxic metals. Annu Rev Pharmacol Toxicol. 1993;33:545-71, https://doi. org/10.1146/annurev.pa.33.040193.002553.

46. Ballatori N. Transport of toxic metals by molecular mimicry. Environ Health Perspect. 2002;110 Suppl. 5:689-94.

47. Burk RF, Foster KA, Greenfield PMK, Kiker KW. Binding of simultaneously administered inorganic selenium and mercury to a rat plasma protein. Proc Soc Exp Biol Med. 1974;145(3):782-5, https://doi.org/10.3181/00379727-14537894.

48. García-Sevillano MA, Jara-Biedma R, González-Fernández M, García-Barrera T, Gómez-Ariza JL. Metal interactions in mice under environmental stress. Biometals. 2013; 26(4):651-66, https://doi.org/10.1007/s10534-013-9642-2.

49. Naganuma A, Imura N. Changes in distribution of mercury and selenium in soluble fractions of rabbit tissues after simultaneous administration. Pharmacol Biochem Behav. 1980;13(4):537-44, https://doi.org/10.1016/0091-30 57(80)90277-4.

50. Carvalho CM, Chew EH, Hashemy SI, Lu J, Holmgren A. Inhibition of the human thioredoxin system. A molecular mechanism of mercury toxicity. J Biol Chem. 2008;283(18): 11913-23, https://doi.org/10.1074/jbc.M710133200.

51. Lucena GM, Franco JL, Ribas CM, Azevedo MS, Meotti FC, Gadotti VM, et al. Cipura paludosa extract prevents methyl mercury-induced neurotoxicity in mice. Basic Clin Pharmacol Toxicol. 2007;101(2):127-31, https://doi. org/10.1111/j.1742-7843.2007.00091.x.

52. Stringari J, Meotti FC, Souza DO, Santos AR, Farina M. Postnatal methylmercury exposure induces hyperlocomotor activity and cerebellar oxidative stress in mice: Dependence on the neurodevelopmental period. Neurochem Res. 2006;31(4):563-9, https://doi.org/10.1007/s11064-0069051-9.

53. Stringari J, Nunes AK, Franco JL, Bohrer D, Garcia SC, Dafre AL, et al. Prenatal methylmercury exposure hampers glutathione antioxidant system ontogenesis and causes long-lasting oxidative stress in the mouse brain. Toxicol Appl
Pharmacol. 2008;15,227(1):147-54, https://doi.org/10.1016/ j.taap.2007.10.010.

54. Grotto D, Barcelos GR, Valentini J, Antunes LM, Angeli JP, Garcia SC, et al. Low levels of methylmercury induce DNA damage in rats: Protective effects of selenium. Arch Toxicol. 2009;83(3):249-54, https://doi.org/10.1007/s00204008-0353-3.

55. Mori N, Yasutake A, Hirayama K. Comparative study of activities in reactive oxygen species production/defense system in mitochondria of rat brain and liver, and their susceptibility to methylmercury toxicity. Arch Toxicol. 2007;81(11):76976, https://doi.org/10.1007/s00204-007-0209-2.

56. Zemolin AP, Meinerz DF, de Paula MT, Mariano DO, Rocha JB, Pereira AB, et al. Evidences for a role of glutathione peroxidase 4 (GPx4) in methylmercury induced neurotoxicity in vivo. Toxicol. 2012;302(1):60-7, https://doi. org/10.1016/j.tox.2012.07.013.

57. Glaser V, Moritz B, Schmitz A, Dafré AL, Nazari EM, Rauh Müller YM, et al. Protective effects of diphenyl diselenide in a mouse model of brain toxicity. Chem Biol Interact. 2013;206(1):18-26, https://doi.org/10.1016/j.cbi.2013.08.002.

58. Glaser V, Martins Rde P, Vieira AJ, Oliveira Ede M, Straliotto MR, Mukdsi JH, et al. Diphenyl diselenide administration enhances cortical mitochondrial number and activity by increasing hemeoxygenase type 1 content in a methylmercury-induced neurotoxicity mouse model. Mol Cell Biochem. 2014;390(1-2):1-8, https://doi.org/10.1007/ s11010-013-1870-9.

59. Raimundo J, Vale C, Canário J, Branco V, Moura I. Relations between mercury, methyl-mercury and selenium in tissues of Octopus vulgaris from the Portuguese coast. Environ Pollut. 2010;158(6):2094-100, https://doi.org/10.1016/ j.envpol.2010.03.005.

60. Liao CY, Zhou QF, Fu JJ, Shi JB, Yuan CG, Jiang GB. Interaction of methylmercury and selenium on the bioaccumulation and histopathology in medaka (Oryzias latipes). Environ Toxicol. 2007;22(1):69-77, https://doi.org/10.1002/ tox. 20236. 
61. Sørmo EG, Ciesielski TM, Øverjordet IB, Lierhagen S, Eggen GS, Berg T, et al. Selenium moderates mercury toxicity in free-ranging freshwater fish. Environ Sci Technol. 2011;45(15):6561-6, https://doi.org/10.1021/es200478b.

62. Koeman JH, van de Ven WS, de Goeij JJ, Tjioe PS, van Haaften JL. Mercury and selenium in marine mammals and birds. Sci Total Environ. 1975;3(3):279-87, https://doi. org/10.1016/0048-9697(75)90052-2.

63. Nielsen JB. Toxicokinetics of mercuric-chloride and methylmercuric chloride in mice. J Toxicol Environ Health 1992;7(1):85-122.

64. Watanabe C, Yin K, Kasanuma Y, Satoh H. In utero exposure to methylmercury and Se deficiency converge on the neurobehavioral outcome in mice. Neurotoxicol Teratol. 1999;21(1):83-8, https://doi.org/10.1016/S0892-03 62(98)00036-1.

65. Beyrouty P, Chan HM. Co-consumption of selenium and vitamin $\mathrm{E}$ altered the reproductive and developmental toxicity of methylmercury in rats. Neurotoxicol Teratol. 2006;28(1):49-58, https://doi.org/10.1016/j.ntt.2005.11.002.

66. Dos Santos APM, Mateus ML, Carvalho CML, Batoréu MCC. Biomarkers of exposure and effect as indicators of the interference of selenomethionine on methylmercury toxicity. Toxicol Lett. 2007;169(2):121-8, https://doi. org/10.1016/j.toxlet.2006.12.007.

67. Hill $\mathrm{CH}$. Reversal of selenium toxicity in chicks by mercury, copper, and cadmium. J Nutr. 1974;104(5):593-8, https:// doi.org/10.1093/jn/104.5.593.

68. Wang A, Barber D, Pfeiffer CJ. Protective effects of selenium against mercury toxicity in cultured Atlantic spotted dolphin (Stenella plagiodon) renal cells. Arch Environ Contam Toxicol. 2001;41(4):403-9, https://doi.org/10.1007/ s002440010266.

69. Parizek J, Ostadalova I. The protective effect of small amounts of selenite in sublimate intoxication. Experientia. 1967;23(2):142-3, https://doi.org/10.1007/BF02135970.

70. Parizek J, Benes I, Ostádalová I, Babický A, Benes J, Lener J. Metabolic interrelations of trace elements. The effect of some inorganic and organic compounds of selenium on the metabolism of cadmium and mercury in the rat. Physiol Bohemoslov. 1969;18(2):95-103.

71. Ganther HE, Goudie C, Kopecky MJ, Wagner P, Oh SH, Hoekstra WG. Selenium: Relation to decreased toxicity of methylmercury added to diets containing tuna. Science. 1972;172:1122-4, https://doi.org/10.1126/science.175. 4026.1122.

72. Peterson SA, Ralston NV, Peck DV, Van Sickle J, Robertson JD, Spate VL, et al. How might selenium moderate the toxic effects of mercury in stream fish of the western U.S.? Environ Sci Technol. 2009;43(10):3919-25, https://doi. org/10.1021/es803203g.

73. Burger J, Gochfeld M, Jeitner C, Donio M, Pittfield T. Interspecific and intraspecific variation in selenium:mercury molar ratios in saltwater fish from the Aleutians: Potential protection on mercury toxicity by selenium. Sci Total Environ. 2012;1(431):46-56, https://doi.org/10.1016/j.scitotenv. 2012.05.024.

74. Beijer K, Jernelöv A. Ecological aspects of mercury-selenium interactions in the marine environment. Environ Health Perspect. 1978;25:43-5, https://doi.org/10.2307/3428707.

75. Branco V, Canário J, Lu J, Holmgren A, Carvalho C. Mercury and selenium interaction in vivo: effects on thioredoxin reductase and glutathione peroxidase. Free Radic Biol Med. 2012;52(4):781-93, https://doi.org/10.1016/j.freeradbiomed.2011.12.002.

76. Fang SC. Interaction of selenium and mercury in the rat. Chem Biol Interact. 1977;17(1):25-40, https://doi.org/10. 1016/0009-2797(77)90069-2.

77. Iwata $\mathrm{H}$, Okamoto $\mathrm{H}$, Ohsawa Y. Effect of selenium on methylmercury poisoning. Res Commun Chem Pathol Pharmacol. 1973;5(3):673-80.

78. Jureša D, Blanusa M, Kostial K. Simultaneous administration of sodium selenite and mercuric chloride decreases efficacy of DMSA and DMPS in mercury elimination in rats. Toxicol Lett. 2005;155(1):97-102, https://doi.org/10.1016/ j.toxlet.2004.08.014. 
79. Bjerregaard P, Fjordside S, Hansen MG, Petrova MB. Dietary selenium reduces retention of methyl mercury in freshwater fish. Environ Sci Technol. 2011;45(22):9793-8, https:// doi.org/10.1021/es202565g.

80. Bjerregaard P, Christensen A. Selenium reduces the retention of methyl mercury in the brown shrimp Crangon crangon. Environ Sci Technol. 2012;46(11):6324-9, https://doi. org/10.1021/es300549y.

81. Naganuma A, Imura N. Mode of in vitro interaction of mercuric mercury with selenite to form high-molecular weight substance in rabbit blood. Chem Biol Interact. 1983;43(3): 271-82, https://doi.org/10.1016/0009-2797(83)90111-4.

82. Sharma DC, Davis PS. Effect of sodium selenite \& selenomethionine on the accumulation \& acute toxicity of mercuric \& methylmercuric chloride in the goldfish Carassius auratus. Indian J Exp Biol. 1980;18(1):82-4.

83. Chung AS, Maines MD, Reynolds WA. Inhibition of the enzymes of glutathione metabolism by mercuric chloride in the rat kidney: Reversal by selenium. Biochem Pharmacol. 1982;31:3093-100, https://doi.org/10.1016/0006-29 52(82)90085-5.

84. Orct T, Lazarus M, Jurasović J, Blanusa M, Piasek M, Kostial K. Influence of selenium dose on mercury distribution and retention in suckling rats. J Appl Toxicol. 2009; 29(7): 585-9, https://doi.org/10.1002/jat.1444.

85. Magos L, Webb M. The effect of selenium on the brain uptake of methylmercury. Arch Toxicol. 1977;38(3):201-7, https://doi.org/10.1007/BF00293654.

86. Naganuma A, Imura N. Bis(methyl mercury)selenide as a reaction product from methylmercury and selenite in rabbit blood. Res Commun Chem Pathol Pharmacol. 1980; 27(1):163-73.

87. Di Simplicio P, Gorelli M, Vignani R, Leonzio C. The differential modulation of the enzymes of glutathione metabolism. Indication of overlapping effects of toxicity and repair in mouse liver and kidney after dietary treatment with methyl mercury and sodium selenite. Biol Trace Elem Res. 1993;36(2):167-81, https://doi.org/10.1007/BF02783176.
88. Ralston NVC, Ralston CR, Blackwell JL, Raymond LJ. Dietary and tissue selenium in relation to methylmercury toxicity. Neurotoxicology. 2008;29(5):802-11, https://doi.org/ 10.1016/j.neuro.2008.07.007.

89. Kobal AB, Prezelj M, Horvat M, Krsnik M, Gibicar D, Osredkar J. Glutathione level after long-term occupational elemental mercury exposure. Environ Res. 2008;107(1):115-23, https://doi.org/10.1016/j.envres.2007.07.001.

90. Goodrich JM, Wang Y, Gillespie B, Werner R, Franzblau A, Basu N. Glutathione enzyme and selenoproteins polymorphisms associate with mercury biomarker levels in Michigan dental professionals. Toxicol Appl Pharmacol. 2011;257(2):301-8, https://doi.org/10.1016/j.ta ap.2011.09.014.

91. Li Y-F, Dong Z, Chen C, Li B, Gao Y, Qu L, et al. Organic selenium supplementation increases mercury excretion and decreases oxidative damage in long-term mercury-exposed residents from Wanshan, China. Environ Sci Technol. 2012;46(20):11313-8, https://doi.org/10.1021/es302241v.

92. Bulat P, Dujić I, Potkonjak B, Vidaković A. Activity of glutathione peroxidase and superoxide dismutase in workers occupationally exposed to mercury. Int Arch Occup Environ Health. 1998;71:37-9.

93. Samir AM, Aref WM. Impact of occupational exposure to elemental mercury on some antioxidative enzymes among dental staff. Toxicol Ind Health. 2011;27(9):779-86, https:// doi.org/10.1177/0748233710397420.

94. Gundacker C, Komarnicki G, Jagiello P, Gencikova A, Dahmen N, Wittmann KJ, et al. Glutathione-Stransferase polymorphism, metallothionein expression, and mercury levels among students in Austria. Sci Total Environ. 2007;385 (1-3):37-47, https://doi.org/10.1016/j.scitotenv.2007.07.033.

95. Custodio HM, Harari R, Gerhardsson L, Skerfving S, Broberg K. Genetic influences on the retention of inorganic mercury. Arch Environ Occup Health. 2005;60(1):17-23, https:// doi.org/10.3200/AEOH.60.1.17-23.

96. Gundacker C, Wittmann KJ, Kukuckova M, Komarnicki G, Hikkel I, Gencik M. Genetic background of lead and mer- 
cury metabolism in a group of medical students in Austria. Environ Res. 2009;109(6):786-96, https://doi.org/10.1016/ j.envres.2009.05.003.

97. Zimniak P, Nanduri B, Pikuła S, Bandorowicz-Pikuła J, Singhal SS, Srivastava SK, et al. Naturally occurring human glutathione s-transferase GSTP1-1 isoforms with isoleucine and valine in position 104 differ in enzymatic properties. Eur J Biochem. 1994;224:893-9, https://doi.org/10.1111/j.14321033.1994.00893.x.

98. Schläwicke-Engström K, Strömberg U, Lundh T, Johansson I, Vessby B, Hallmans G, et al. Genetic variation in glutathione-related genes and body burden of methylmercury. Environ Health Perspect. 2008;116(6):734-9, https://doi. org/10.1289/ehp.10804.

99. Méplan C, Nicol F, Burtle BT, Crosley LK, Arthur JR, Mathers JC, et al. Relative abundance of selenoprotein P isoforms in human plasma depends on genotype, Se intake, and cancer status. Antioxid Redox Signal. 2009;11(11): 2631-40, https://doi.org/10.1089/ars.2009.2533.

100. Thornalley PJ, Vasak M. Possible role for metallothionein in protection against radiation-induced oxidative stress. Kinetics and mechanism of its reaction with superoxide and hydroxyl radicals. Biochim Biophys Acta. 1985;827(1): 36-44, https://doi.org/10.1016/0167-4838(85)90098-6.

101. Wang Y, Goodrich JM, Gillespie B, Werner R, Basu N, Franzblau A. An investigation of modifying effects of metallothionein single-nucleotide polymorphisms on the association between mercury exposure and biomarker levels. Environ Health Perspect. 2012;120(4):530-4, https:// doi.org/10.1289/ehp.1104079.

102. Berglund M, Lind B, Björnberg KA, Palm B, Einarsson Ö, Vahter M. Inter-individual variations of human mercury exposure biomarkers: A cross-sectional assessment. Environ Health. 2005;4:20, https://doi.org/10.1186/1476-069X-4-20.

This work is available in Open Access model and licensed under a Creative Commons Attribution-NonCommercial 3.0 Poland License - http://creativecommons.org/ licenses/by-nc/3.0/pl/deed.en. 